Journal of Extension Education

Vol. 29 No. 4, 2017

DOI:https: / / doi.org/10.26725/JEE.2017.4.29.5958-5965

\title{
Extent of Awareness of Distance Learners of Tamil Nadu Agricultural University
}

\section{T.R. Sridevi Krishnaveni ${ }^{1}$, P. Balasubramaniam ${ }^{2}$, A. Anusuya ${ }^{3}$ and S. Vasanthapriya ${ }^{4}$}

\begin{abstract}
The present research was framed to assess the awareness level of distance learners of Tamil Nadu Agricultural University. Three certificate courses were selected based on maximum number of enrollment, viz, Gardening \& landscaping, Mushroom production $\&$ Solid waste management and vermicomposting. Ex-post facto research design was employed. A total of 150 respondents were selected from the three courses by equal allocation method proportionate random sampling. A well-structured questionnaire was prepared and the information was collected by sending questionnaires through post. The 108 individuals who responded were taken as the sample for the study. The results of the research pointed out that nearly three-fourths of the respondents possessed medium level of awareness on selected technologies.
\end{abstract}

Keywords : Awareness, Certificate course; Tamil Nadu Agricultural University; Open and Distance Learning

\section{INTRODUCTION}

Distance education, is a type that can be included under non-formal education. It is a structured learning in which the student and instructor are separated by place, and sometimes separated by time. It was once considered as a special form of education using nontraditional delivery systems but now has become an important concept in mainstream education even in agricultural education.

The conventional agricultural schools at national, regional and state level could accommodate only two per cent of youth who desire to opt for agricultural education. Quality wise, distance agricultural education has inherent limitations about practical sessions and laboratory experimentations and interactive learning. Tamil Nadu Agricultural University (TNAU), Coimbatore beyond its tri-fold function started a separate directorate for open and distance learning (ODL) for transfer

$1 \& 4$ - Ph.D., Scholars and 3. P.G. Scholar, Department of Agricultural Extension and Rural Sociology, TNAU, Coimbatore; 2 - Professor, Department of Social Sciences, ADAC\&RI, Trichy. Tamil Nadu 
of technology with an objective to reach the unreached. Several types of courses are being offered at TNAU in distance mode and certificate course is one among them. This study has made an attempt to study the extent of awareness on critical technologies enhanced through ODL certificate courses of TNAU.

\section{METHODOLOGY}

Tamil Nadu Agricultural University offers different certificate courses through Open and Distance Learning (ODL) mode. Among the entire certificate courses only three courses were selected based on maximum number of enrollment, viz, Gardening \& landscaping, Mushroom production and Solid waste management \& vermicomposting. Ex-post research design was employed. A total of 150 respondents were selected from the entire three courses by equal allocation method proportionate random sampling. A well-structured questionnaire was prepared and the information was collected through mailed questionnaires method. After giving considerable period of time to send back their responses, 108 registered learners were responded. These 108 respondents were taken as the sample for the study.

\section{FINDINGS AND DISCUSSION}

\section{Profile of the Respondents}

Among the respondents, nearly half of the respondents (43.52\%) who had enrolled in certificate courses in distance learning mode belonged to middle age group i.e, 35 to 45 years. More than half of the respondents (63.89\%) enrolled in the certificate courses at Directorate of Open and Distance Learning (DODL) were male and 36.11 per cent of respondents were female. Majority of them (30.60\%) were with higher secondary level education $(28.70 \%)$ and secondary level education $(15.70 \%)$. One third of them (33.30 $\%)$ had job in private sector followed by equal proportion of respondents having professions as self employment (23.20 $\%)$ and farming (22.20 \%). Considerable per cent of them belonged to unemployed category (13.90\%). The respondents were distributed equally among urban and rural background category with 54.60 per cent and 45.40 per cent respectively. The overall analysis revealed that more than half of the respondents $(66.70 \%)$ had medium level of information seeking behavior followed by 19.40 per cent of them with low information seeking behavior.

\section{Awareness}

Awareness was operationalized as the respondent's familiarity with the subject matter dealt in certificate courses in distance mode. From the table 1, it could be observed that nearly three fourth of the respondents $(74.00 \%)$ possessed medium level of awareness followed by 13.90 per cent of respondents with low level of awareness and 12.10 per cent of respondents with high level of awareness. Being a short duration vocational course, the certificate courses offered at DODL, 
TNAU had imparted knowledge about all basic technologies to launch and manage an enterprise. This might be the reason for their increased level of awareness.

Table 1.

Distribution of Respondents According to Their Level of Awareness

$(n=108)$

\begin{tabular}{|c|c|c|c|c|c|c|c|c|c|}
\hline \multirow[t]{2}{*}{$\begin{array}{l}\text { S1. } \\
\text { No. }\end{array}$} & \multirow[t]{2}{*}{ Category } & \multicolumn{2}{|c|}{$\begin{array}{l}\text { Gardening \& } \\
\text { Landscaping } \\
\text { (n }=34)\end{array}$} & \multicolumn{2}{|c|}{$\begin{array}{c}\text { Mushroom } \\
\text { Production } \\
\qquad(\mathrm{n}=\mathbf{3 8})\end{array}$} & \multicolumn{2}{|c|}{$\begin{array}{c}\text { Solid Waste } \\
\text { Management \& } \\
\text { Vermicomposting } \\
(\mathrm{n}=36)\end{array}$} & \multicolumn{2}{|c|}{$\begin{array}{c}\text { Total } \\
(\mathrm{n}=108)\end{array}$} \\
\hline & & No & $\%$ & No & $\%$ & No & $\%$ & No & $\%$ \\
\hline 1. & Low & 2 & 5.90 & 4 & 10.50 & 9 & 25.00 & 15 & 13.90 \\
\hline 2. & Medium & 24 & 70.60 & 29 & 79.30 & 27 & 75.00 & 80 & 74.00 \\
\hline 3. & High & 8 & 23.50 & 5 & 13.20 & 0 & 0.00 & 13 & 12.10 \\
\hline Tot: & & 34 & 100.00 & 38 & 100.00 & 36 & 100.00 & 108 & 100.00 \\
\hline
\end{tabular}

The relationship between the independent variables and awareness is given in Table 2 .

Table 2. Correlation between the Independent variables and Awareness of Respondents

\begin{tabular}{|c|l|c|c|c|}
\hline \multirow{2}{*}{$\begin{array}{c}\text { Variable } \\
\text { No. }\end{array}$} & \multirow{2}{*}{ Variables } & \multicolumn{2}{|c|}{ 'r' value } & \\
\cline { 2 - 5 } X1 & Age & $0.253 \mathrm{NS}$ & $0.763^{* *}$ & Vermicomposting \\
\hline X2 & Gender & $-0.224 \mathrm{NS}$ & $0.206 \mathrm{NS}$ & $-0.038 \mathrm{NS}$ \\
\hline X3 & $\begin{array}{l}\text { Educational } \\
\text { status }\end{array}$ & $0.440^{* *}$ & $-0.004 \mathrm{NS}$ & $0.844^{* *}$ \\
\hline X4 & Marital status & $-3.07 \mathrm{NS}$ & $0.370^{*}$ & $-0.194 \mathrm{NS}$ \\
\hline X5 & $\begin{array}{l}\text { Occupational } \\
\text { status }\end{array}$ & $-0.013 \mathrm{NS}$ & $0.086 \mathrm{NS}$ & $-0.267 \mathrm{NS}$ \\
\hline X6 & Annual income & $0.000 \mathrm{NS}$ & $-0.058 \mathrm{NS}$ & $0.804^{* *}$ \\
\hline X7 & Job experience & $0.228 \mathrm{NS}$ & $0.220 \mathrm{NS}$ & $0.171 \mathrm{NS}$ \\
\hline X8 & $\begin{array}{l}\text { Rural-Urban } \\
\text { background }\end{array}$ & $0.116 \mathrm{NS}$ & $-0.363^{*}$ & $-0.638^{* *}$ \\
\hline X9 & $\begin{array}{l}\text { Geographic } \\
\text { distance }\end{array}$ & $-0.121 \mathrm{NS}$ & $-0.883^{* *}$ & $-0.944^{* *}$ \\
\hline
\end{tabular}




\begin{tabular}{|c|c|c|c|c|}
\hline \multirow{2}{*}{$\begin{array}{c}\text { Variable } \\
\text { No. }\end{array}$} & \multirow{2}{*}{ Variables } & \multicolumn{2}{|c|}{ 'r' value } & \multirow[b]{2}{*}{ Vermicomposting } \\
\hline & & Landscaping & Mushroom & \\
\hline $\mathrm{X} 10$ & $\begin{array}{l}\text { Medium of } \\
\text { instruction }\end{array}$ & $0.376^{*}$ & $-0.252 \mathrm{NS}$ & $-0.928^{* *}$ \\
\hline $\mathrm{X} 11$ & $\begin{array}{l}\text { Computer } \\
\text { knowledge }\end{array}$ & $0.269 \mathrm{NS}$ & $-0.029 \mathrm{NS}$ & $0.673^{* *}$ \\
\hline $\mathrm{X} 12$ & $\begin{array}{l}\text { Information } \\
\text { seeking behavior }\end{array}$ & $0.937^{* *}$ & $0.719^{* *}$ & $0.828^{* *}$ \\
\hline $\mathrm{X} 13$ & $\begin{array}{l}\text { Information } \\
\text { sharing behavior }\end{array}$ & $0.810^{* *}$ & $0.799 * *$ & $0.945^{* *}$ \\
\hline $\mathrm{X} 14$ & Job aspiration & $0.353^{*}$ & $0.827^{* *}$ & $0.664 * *$ \\
\hline $\mathrm{X} 15$ & $\begin{array}{l}\text { Determinant } \\
\text { factors }\end{array}$ & $-0.891^{* *}$ & $0.916^{* *}$ & $-0.850 * *$ \\
\hline $\mathrm{X} 16$ & $\begin{array}{l}\text { Economic } \\
\text { motivation }\end{array}$ & $0.929 * *$ & $0.730^{* *}$ & $0.969 * *$ \\
\hline $\mathrm{X} 17$ & $\begin{array}{l}\text { Attitude towards } \\
\text { entrepreneurship }\end{array}$ & $0.923^{* *}$ & $0.862^{* *}$ & $0.910^{* *}$ \\
\hline $\mathrm{X} 18$ & $\begin{array}{l}\text { Evaluation of } \\
\text { syllabus }\end{array}$ & $0.872^{* *}$ & $0.963^{* *}$ & $0.860^{* *}$ \\
\hline $\mathrm{X} 19$ & $\begin{array}{l}\text { Evaluation of } \\
\text { course outline }\end{array}$ & $0.845^{* *}$ & $0.960^{* *}$ & $0.841^{* *}$ \\
\hline $\mathrm{X} 20$ & $\begin{array}{l}\text { Evaluation of } \\
\text { course content }\end{array}$ & $0.892^{* *}$ & $0.931^{* *}$ & $0.899 * *$ \\
\hline $\mathrm{X} 21$ & $\begin{array}{l}\text { Evaluation of } \\
\text { course material }\end{array}$ & $0.813^{* *}$ & $0.793^{* *}$ & $0.838^{* *}$ \\
\hline $\mathrm{X} 22$ & $\begin{array}{l}\text { Evaluation of } \\
\text { physical facilities }\end{array}$ & $0.0780 * *$ & $0.860^{* *}$ & $0.919^{* *}$ \\
\hline $\mathrm{X} 23$ & $\begin{array}{l}\text { Evaluation } \\
\text { of modes of } \\
\text { teaching }\end{array}$ & $0.929 * *$ & $0.895^{* *}$ & $0.792^{* *}$ \\
\hline $\mathrm{X} 24$ & \begin{tabular}{|l}
$\begin{array}{l}\text { Evaluation of } \\
\text { teaching aids }\end{array}$ \\
\end{tabular} & $0.946^{* *}$ & $0.860^{* *}$ & $0.853^{* *}$ \\
\hline $\mathrm{X} 25$ & $\begin{array}{l}\text { Evaluation } \\
\text { of teaching } \\
\text { methods }\end{array}$ & $0.935^{* *}$ & $0.848^{* *}$ & $0.773^{* *}$ \\
\hline
\end{tabular}




\begin{tabular}{|c|l|c|c|c|}
\hline \multirow{2}{*}{$\begin{array}{c}\text { Variable } \\
\text { No. }\end{array}$} & \multirow{2}{*}{ Variables } & \multicolumn{2}{|c|}{ 'r' value } & \\
\cline { 3 - 5 } & Landscaping & Mushroom & Vermicomposting \\
\hline X26 & $\begin{array}{l}\text { Evaluation of } \\
\text { teacher-taught } \\
\text { interaction }\end{array}$ & $0.768^{* *}$ & $0.883^{* *}$ & $0.933^{* *}$ \\
\hline X27 & $\begin{array}{l}\text { Evaluation of } \\
\text { administration }\end{array}$ & $0.821^{* *}$ & $00.955^{* *}$ & $0.878^{* *}$ \\
\hline
\end{tabular}

*- significant at $5 \%$ level

** - Significant at $1 \%$ level

NS - Not Significant

\section{LANDSCAPING}

From Table 2, it could be inferred that out of 27 variables, 15 variables viz, educational status (X3), information seeking behavior (X12), information sharing behavior (X13), economic motivation (X16), attitude towards entrepreneurship (X17), evaluation of syllabus (X18), course outline (X19), course content (X20), course material (X21), physical facilities (X22), modes of teaching (X23), teaching aids (X24), teaching methods (X25), teacher-taught interaction (X26) and administration (X27) had a positive significant relationship at one percent level. Determinant factor (X15) had negative significant relationship at $1 \%$ level of significance with the awareness level of distance learners of gardening and landscaping course of DODL, TNAU. Job aspiration (X14) and Medium of instruction (X10) had a positive and significant relationship with awareness at $5 \%$ level of significance.
Majority of the respondents (39.50\%) belonged to middle age group and hence age had a positive influence towards awareness. Majority (64.70 \%) had medium level of information seeking behavior and $70.60 \%$ of the respondents' possessed good information sharing behavior. As the respondents possessed these characteristics they would share information with their known circle of people and hence information seeking and sharing behavior had positive relationship with the awareness.

More than half of the respondents $(62.00 \%)$ and majority of the respondents (82.00\%) possess medium economic motivation and medium attitude towards entrepreneurship. These factors reveal the respondents' interest towards livelihood upliftment and determination to achieve their career goals. Therefore, it had a positive influence on awareness.

As far as course effectiveness is concerned majority of the respondents felt satisfied with every aspect of the course like syllabus, course outline, course content, course material, PCP and administration. As the effectiveness increases the commitment, interest and 
involvement of the respondents towards the course, institution and subject. In turn the level of awareness also rises. Hence, course effectiveness had a positive link with awareness.

Marital status explained that, 58.00 per cent of respondents were married and had children. The respondents with this marital status have higher desire to develop their family and also to achieve higher goals. Hence, it had a positive link with awareness.

As the geographic distance increases the frequency of respondents to attend the Personal Contact Classes (PCP) decreases, which, ultimately leads to less awareness about concepts related to the subject. Hence, geographic distance was linked negatively to awareness. Similarly 47.40 per cent of respondents were with rural background. Rural areas are lagging a little from urban areas in terms of social contact and ICT developments hence it might have affected the awareness level.

\section{Mushroom Production}

From Table 2, it could be inferred that out of 27 variables, 17 variables viz, age (X1), information seeking behavior (X12), information sharing behavior (X13), job aspiration (X14), determinant factors (X15), economic motivation (X16), attitude towards entrepreneurship (X17), evaluation of syllabus (X18), course outline (X19), course content (X20), course material (X21), physical facilities (X22), modes of teaching (X23), teaching aids (X24), teaching methods (X25), teacher-taught interaction (X26) and administration (X27) show positive significant relationship at one percent level. Marital status (X4) had a positive influence at $5 \%$ level of significance. Geographic distance had negative significant relationship at $1 \%$ level of significance and rural-urban background had negative influence at $5 \%$ significance level on the awareness level of the respondents enrolled with the mushroom production course offered by DODL, TNAU.

Majority of the respondents belonged to the educational status of undergraduate level of education, had medium level of information seeking behavior and possessed medium level of economic motivation and attitude toward entrepreneurship respectively. These factors might have contributed to their determination to achieve their career goal, hence it had a positive influence with awareness.

As far as course effectiveness is concerned, majority of the respondents felt satisfied with every aspect of the course like syllabus, course outline, course content, course material, PCP and administration. As the effectiveness increases, it creates a positive attitude among the respondents towards the institute, facilitators and subject hence it ultimately lead to increase in awareness among the respondents. 
Majority of the respondents had their previous education through mother tongue (i.e. Tamil) as the medium of instruction, as the certificate courses were also offered in their mother tongue at DODL, TNAU, the level of understanding was high and easy hence medium of instruction had positive relationship with the awareness.

\section{Solid Waste Management and Vermicomposting}

From Table 2, it could be inferred that out of 27 variables, 19 variables viz, age (X1), educational status (X3), annual income (X6), computer knowledge (X11), information seeking behavior (X12), information sharing behavior (X13), job aspiration (X14), economic motivation (X16), attitude towards entrepreneurship (X17), evaluation of syllabus (X18), course outline (X19), course content (X20), course material (X21), physical facilities (X22), modes of teaching (X23), teaching aids (X24), teaching methods (X25), teacher-taught interaction (X26) and administration (X27) had positive significant relationship at one percent level with the awareness level of the beneficiaries of solid waste management and vermicomposting course offered at DODL, TNAU.

Rural-urban background (X8), geographic distance (X9), medium of instruction (X10) and determinant factors (X15) had negatively significant relationship at $1 \%$ level of significance.
Majority of the respondents $(52.80$ $\%)$ belonged to middle age group. This age group people have a strong commitment towards family and strong desire to achieve their goals to uplift its socioeconomic condition. They were more attentive to gather information; hence age had a positive influence towards awareness.

As regards, the effectiveness of the course effectiveness, majority of the respondents felt satisfied with every aspects of the course like syllabus, course outline, course content, course material, PCP and administration. Hence, course effectiveness had a positive link with awareness.

\section{CONCLUSION}

From this study, it is learnt that most of the respondents belonged to urban population and hence efforts should be taken to create awareness about the certificate courses among rural population. Refinement of course material with more pictures and illustrations considering the heterogeneous nature of the group is highly needed.

\section{REFERENCES}

Archana, K. P. (2014). Impact of Certificate Courses Offered through ODL Mode at TNAU. Unpublished M.Sc. (Ag.) Thesis, Agricultural College and Research Institute, TNAU, Coimbatore.

Asokhan, M. (2006). Empowerment of Rural Women through Self-help Groups - An Empirical Analysis. Unpublished 
Ph. D. Thesis, Agricultural College and Research Institute, TNAU, Coimbatore.

Ghani, E. K., Said, J \& Nasir, N. M. (2008). Determinants of Malaysian Adult Learners in the Klang Valley. Proceedings of ICDE International Conference held during November 1923. New Delhi.

Thilagam, J. (2009). An Evaluation Study on Gratification, Perception and Problems of ODL Students of TNAU.
Unpublished M.Sc. (Ag.) Thesis, Agricultural College and Research Institute, TNAU, Coimbatore.

Verma, S. R. (2014). Impact of Post Graduate Course on Sugarcane Technology Offered through Open and Distance Learning Mode. Unpublished M.Sc. (Ag.) Thesis, Agricultural College and Research Institute, TNAU, Coimbatore. 